\title{
Effects of Nipah Virus in today's World
}

Available online at www.ijistweb.com

\section{REVIEW ARTICLE}

\author{
Dhiraj Kumar Singh*, Rakhi Ahuja, Nagendra Kumar Singh
}

Delhi Pharmaceutical Sciences and Research University, New Delhi, India

*Corresponding Author's E-mail: aaaryansingh007@gmail.com

\begin{abstract}
The effect of Nipah Virus Infection is increasing day by day in today's scenario and more number of cases are found in various countries. In India it was discovered in Sikkim, Siliguri and West Bengal. It is near borders with China, Bangladesh, Nepal, and Sikkim. The primary pathways of transmission is from bats to people, in Bangladesh its transformed via contamination of raw date palm sap by bats with subsequent consumption by humans and through infection of domestic animals (cattle, pigs, and goats), presumably from consumption of food contaminated with bat saliva or urine with subsequent transmission to people. It is found in both species of humans as well as animals more number of deaths was found in the both spices, hence zoonotics.

Laboratory investigations at the time of the outbreak did not show or identify an infectious agent. Approximately half of recognized Nipah cases in Bangladesh developed their disease following person to person transmission of the virus. Efforts to prevent transmission should focus on decreasing bat access to date palm sap and reducing family members' and friends' exposure to infected patients' saliva or body fluids.
\end{abstract}

Keywords: Nipah Virus (NiV), Pteropus, Virus infection, Optical densities (OD).

\section{INTRODUCTION}

Nipah Virus (NiV) is an emerging infectious disease which first surfaced in domestic pigs in Malaysia and Singapore in the 1998/9. There is evidence of Nipah infection among several species of domestic animals including dogs, cats, goats, and horses. Sheep may also be affected. However, since the initial outbreak it has primarily affected humans in different parts of the world. The disease causes respiratory and sometimes nervous signs in pigs. It has disastrous zoonotic potential.

The organism which causes Nipah Virus encephalitis is an RNA virus of the family Paramyxoviridae, genus Henipavirus, and is closely related to Hendra virus. Hendra virus, formerly known as equine morbillivirus pneumonia or acute equine respiratory syndrome, is an acute, viral respiratory infection of horses and humans that has been reported in Australia. Nipah Virus infection, also known as Nipah Virus encephalitis, was first isolated and described in the year 1999. The name, Nipah, is derived from the village in Malaysia where the person from whom the virus was first isolated surrender to the disease.

In January and February of 2001, an outbreak of febrile illness with altered sensorial was observed in Siliguri, West Bengal, India. Siliguri is an important commercial center with an approximate population of 500,000. Sharing borders with China, Bangladesh, Nepal, and Sikkim. The outbreak occurred among hospitalized patients, family contacts of the patients, and medical staff of 4 hospitals. Nipah virus $(\mathrm{NiV})$, a recently emergent, zoonotic paramyxovirus was implicated as the cause of a highly fatal (case-fatality ratio $38 \%-75 \%$ ), febrile humanencephalitis in Malaysia and Singapore in 1999 [1]. Bangladesh during the winters of 2001, 2003, and 2004 [3-6].

The natural reservoir of $\mathrm{NiV}$ is presumed to be fruit bats of the genus Pteropus. Evidence of $\mathrm{NiV}$ infection wasdetected in these bats in Malaysia, Bangladesh, and Cambodia.[7-10] In the Malaysian outbreak, NiV was introduced 
into the pig population, and most of the human cases resulted from exposure to ill pigs.[2]

Thus, Nipah virus is an enveloped, nonsegmented, negative strand RNA virus. Six structural proteins are encoded by the Nipah virus genome: the nucleoprotein $\mathrm{N}$, phosphoprotein $\mathrm{P}$, matrix protein $\mathrm{M}$, the two envelope glycoproteins $F$ (fusion) and $G$ (receptor binding) and the RNA-dependent RNA polymerase L [11].

Serological and virus detection studies have found evidence for Nipah virus infection in multiple flying fox species, such as the island flying fox (Pteropushypomelanus), the Malayan flying fox (Pteropusvampyrus), the Indian flying fox (Pteropusgiganteus) and Lyle's flying fox (Pteropuslylei) [11].

\section{History of cases detection background}

$\mathrm{NiV}$ infection has not been detected in Malaysia or Singapore after 1999, but recurring (almost annual) human cases of Nipah encephalitis with very high case fatalities in Bangladesh and sporadic outbreaks in India since 2001 (Table1)

Table 1. Morbidity and mortality in humans due to NiV, India-Bangladesh $[12,13]$ D. D. Kulkarni et al.

\begin{tabular}{|c|c|c|c|c|}
\hline Year/month & Location & $\begin{array}{l}\text { No. } \\
\text { cases }\end{array}$ & $\begin{array}{l}\text { No. } \\
\text { deaths }\end{array}$ & $\begin{array}{c}\text { Case } \\
\text { fatality }(\%)\end{array}$ \\
\hline Jan-Feb 2001 & Siliguri (India) & 66 & 45 & 68 \\
\hline $\begin{array}{l}\text { Apr-May } \\
2001\end{array}$ & Meherpur (Bangladesh) & 13 & 9 & 69 \\
\hline Jan 2003 & Naogaon (Bangladesh) & 12 & 8 & 67 \\
\hline Jan 2004 & Rajbari(Bangladesh & 31 & 23 & 74 \\
\hline Apr 2004 & Faridpur (Bangladesh) & 36 & 27 & 75 \\
\hline Jan-Mar 2005 & Tangail (Bangladesh) & 12 & 11 & 92 \\
\hline Jan-Feb 2007 & Thakurgaon (Bangladesh) & 7 & 3 & 43 \\
\hline Mar 2007 & Kushtia, Pabna, Natore (Bangladesh & 8 & 5 & 13 \\
\hline April 2007 & Nadia (India) & 5 & 5 & 101 \\
\hline Feb 2008 & Manikgonj (Bangladesh) & 4 & 4 & 101 \\
\hline Apr 2008 & Rajbari and Faridpur (Bangladesh & 7 & 5 & 71 \\
\hline Jan 2009 & $\begin{array}{l}\text { Gaibandha, Rangpur and Nilphamari } \\
\text { (Bangladesh) }\end{array}$ & 3 & 0 & 0 \\
\hline Jan 2009 & Rajbari (Bangladesh) & 1 & 1 & 101 \\
\hline Feb-Mar 2010 & $\begin{array}{l}\text { Faridpur, Rajbari, Gopalganj, Madaripur } \\
\text { (Bangladesh) }\end{array}$ & 16 & 14 & 87.5 \\
\hline Jan-Feb 2011 & $\begin{array}{l}\text { Lalmohirhat, Dinajpur, Comilla, Nilphamari } \\
\text { and Rangpur (Bangladesh) }\end{array}$ & 44 & 40 & 91 \\
\hline Feb 2012 & $\begin{array}{l}\text { Joypurhat, Rajshahi, Natore, Rajbari and } \\
\text { Gopalganj (Bangladesh) }\end{array}$ & 12 & 10 & 83 \\
\hline Jan-Feb 2013 & $\begin{array}{l}\text { Gaibandha, Natore, Rajshahi, Naogaon, } \\
\text { Rajbari, Pabna, } \\
\text { Jhenaidah, Mymensingh (Bangladesh) }\end{array}$ & 12 & 10 & 83 \\
\hline Total & & 292 & 221 & 75.7 \\
\hline
\end{tabular}

The above table 1 shows the detailed account of the first NiV outbreak in India (Siliguri, West Bengal) during 2001 has been published in various reports $[14,15]$. An outbreak of acute encephalitis occurred in Siliguri (West Bengal) town of India between the months of January 31 and February 23, 2001. A total no. of 66 possible human cases out of which 45 deaths were reported. Later, the clinical material obtained during the Siliguri outbreak was retrospectively analyzed for evidence of $\mathrm{NiV}$ infection [13]. Analysis of the limited sequence data suggested that the NiV strains associated with the outbreak were more closely related to $\mathrm{NiV}$ isolated in 
Bangladesh than to $\mathrm{NiV}$ isolated in Malaysia [14].

In the Malaysian outbreak, pigs were the intermediate hosts. NiV was isolated from fruit bats in Malaysia [16]

Fruit bats with antibodies to $\mathrm{NiV}$ were captured in the outbreak areas of Bangladesh but no intermediate animal host was identified. In Bangladesh, NiV might have been transmitted to humans by direct contact with bats or indirectly by contact with material contaminated by bats. Person-to-person spread was also noted during the 2004NiV outbreak in Faridpur, Bangladesh $[17,18]$. The range of Pteropus giganteus, one of the flying foxes commonly found in South Asia [19] includes West Bengal. Therefore, the range of the proposed natural reservoir for $\mathrm{NiV}$ extends into northeastern India. Since the geographical features of West Bengal are similar to those of Bangladesh, environmental circumstances that favor transmission of $\mathrm{NiV}$ to humans would also likely be same in West Bengal. Many of the epidemiologic features of the outbreak in Siliguri were similar to those of the recent NiV outbreaks in Bangladesh.

Analysis of the limited sequence data suggested that the NiV strains associated with the outbreak were more closely related to $\mathrm{NiV}$ isolated in Bangladesh than to NiV isolated in Malaysia. These data extend the previous observation that viruses circulating in different areas have unique genetic signatures and suggest that these strains may haveco-evolved within local natural reservoirs [20, 21]. After 2001, the second NiV outbreak was reported in West Bengal in India in 2007. Between 11 and 28 April 2007, Krishnan [22] reported 30 cases of fever with acute respiratory distress and/or neurological symptoms from Nadia district of West Bengal in India. The cases presented mainly with fever, headache and bodyache with a few cases having episodes of vomiting, disorientation, respiratory distress. Five cases ended fatally within 3-10 days of onset. However, Arankalle et al. [23] investigated the same outbreak and stated that similar other cases had not been reported from the village or the surrounding area, thus showed case fatality (5/5) as $100 \%$. They also amplified full-genome sequence of $\mathrm{NiV}$ (18252 nt) from lung tissue that showed $99.2 \%$ nucleotide and
99.8 \% amino acid identity with the Bangladesh2004 isolate, suggesting a common source of the virus.

\section{NIPAH VIRUS DISEASE IN HUMANS}

Human Nipah virus (NiV) infection was first recognized in a large outbreak of 276 reported cases in peninsular Malaysia and Singapore from September 1998 through May 1999 [24-26]. Most cases had contact with sick pigs [27]. Cases presented primarily with encephalitis; $39 \%$ died $[26,28]$. Autopsy studies noted diffuse vasculitis most prominently involving the central nervous system with intense immuno staining of endothelial cells with anti-Nipah virus hyperimmune serum [24]. The virus, a member of the recently designated genus Henipavirus, within the family Paramyxoviridae, was first isolated from a patient from Sungai Nipah village [24,26]. The human outbreak of Nipah infection ceased after widespread deployment of personal protective equipment to people contacting sick pigs, restriction on livestock movements, and culling over 900,000 pigs [29].

Large fruit bats of the genus Pteropus appear to be the natural reservoir of NiV. In Malaysia the sero prevalence of neutralizing antibodies to $\mathrm{NiV}$ in colonies of Pteropus vampyrus and $\mathrm{P}$. hypomelanus ranged from $7-58 \%$ [30,31]. Antibodies against henipaviruses have been identified in Pteropus bats wherever they have been tested including Cambodia, Thailand, India, Bangladesh and Madagascar [32-36]. NiV was isolated from urine specimens collected underneath a $\mathrm{P}$. hypomelanus roost and from partially eaten fruit dropped during feeding activity in Malaysia [27], from urine collected underneath a P. lylei roost in Cambodia [32], and from saliva and urine of $P$. lylei in Thailand [33]. Experimental infection of Pteropus bats with NiV does not cause illness in the bats [38]. Surveys of rodents and other animals have not identified other wildlife reservoirs for $\mathrm{NiV}$ [30, 35]. Over 50 species of Pteropus bats live in South and South East Asia [39]. P. giganteus, the only Pteropus species found in Bangladesh, is widely distributed across the country and frequently has antibody to $\mathrm{NiV}[35,40]$.

The growth of large intensively managed commercial pig farms in Malaysia with fruit trees on the farm created an environment where 
bats could drop partially eaten fruit contaminated with NiV laden bat saliva into pig stalls. The pigs could eat the fruit, become infected with $\mathrm{NiV}$, and efficiently transmit virus to other pigs because of the dense pig population on the farms, frequent respiratory shedding of the virus among infected pigs [41], and the pigs' high birth rate that regularly brought newly susceptible young pigs into the population at risk [42].

\section{Clinical disease}

Nipah virus infected patients generally present with fever and altered mental status; neurological signs of disease progress over time, leading to coma and ultimately death. [43-45] Although neurological disease is the main

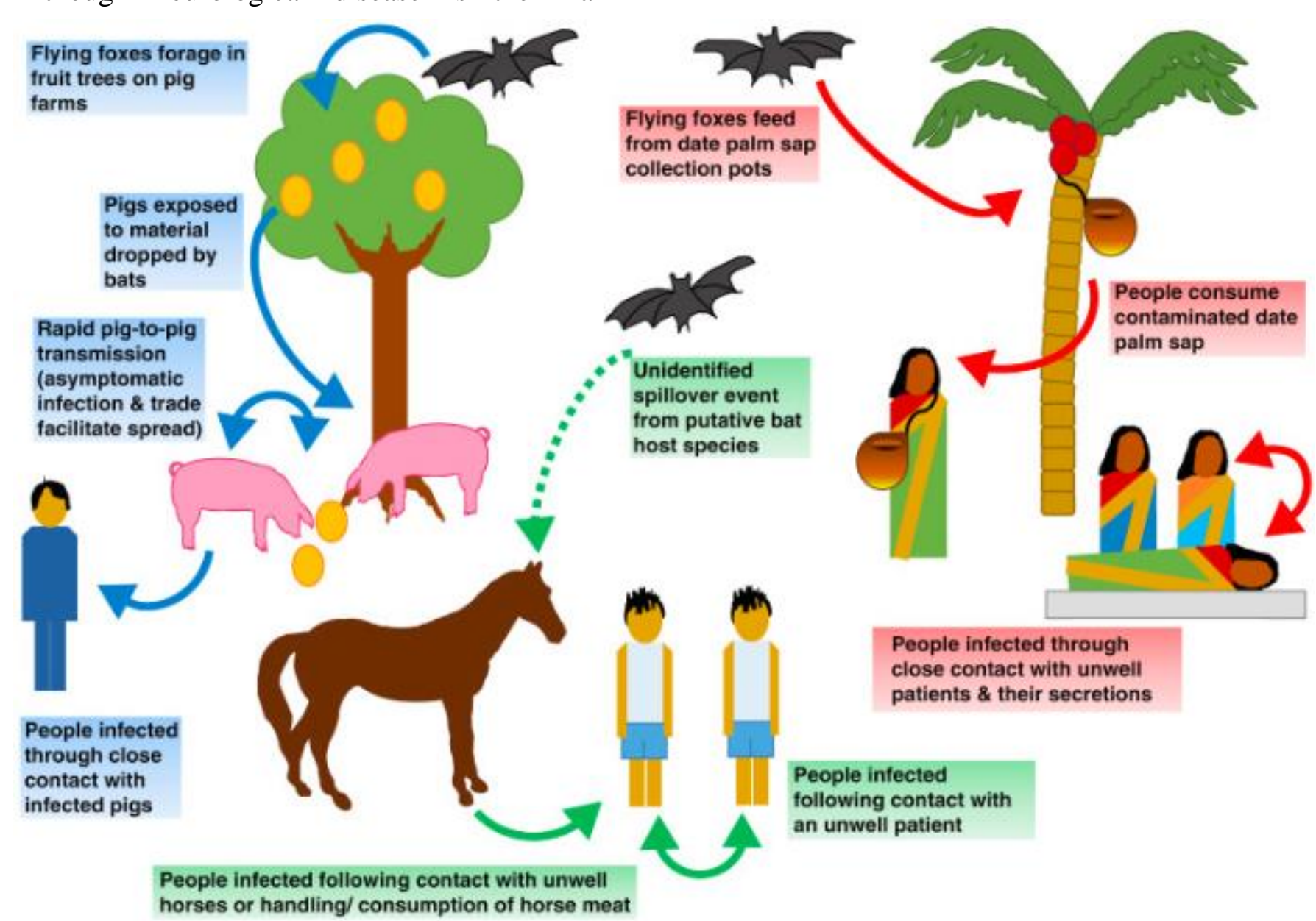

Figure 1: Pathways transmission of Nipah Virus

All available data on histopathological changes in humans infected with Nipah virus were obtained in a single study performed during the Nipah virus outbreak in Malaysia and Singapore. The main site of infection in Nipah virus patients was the endothelium. Systemic vasculitis was complication with Nipah virus infection, respiratory disease also occurs to varying degrees: during the 1998-1999 outbreak in Malaysia and Singapore $25 \%$ of cases presented with respiratory disease, vs. $69 \%$ of cases in Bangladesh [46]. The case-fatality ratio in Nipah virus infected people is high $40 \%$ during the outbreak in Malaysia and Singapore; in Bangladesh and India the overall case-fatality ratio is $70 \%$, but may be $100 \%$ in individual outbreaks. Late-onset or relapse encephalitis has been observed; in one case this late-onset encephalitis occurred 11 years after the initial Nipah virus infection. [47-49].

\section{Histopathological findings}


Nipah virus as indicated by immunehistochemistry. In the lungs, fibrinoid necrosis was noted in alveoli adjacent to small vessels with vasculitis, and alveolar hemorrhage and pulmonary oedema were observed frequently. In the spleens of many cases, acute necrotizing lesions in the periarteriolar sheaths and lymphoid depletion were observed. In the kidneys of one third of patients focal glomerular fibrinoid necrosis was seen [50].

Figure 1 is illustrating the pathways transmission of Nipah Virus, how it transmits from one organism to another. Nipah virus (NiV) infection is a newly emerging zoonotic disease that causes severe disease in both animals and humans. The natural host of the virus are fruits, bats of the Pteropodidae Family, Pteropus genus NiV was first identified during an outbreak of the disease that took place in Kampung Sungai Nipah, Malaysia in 1998. In the above figure it can be seen that the transmission occurs from flying bats to trees, as the bats sit on the trees infect the fruits and parts of the plants and from there it transfers directly into animals as they live on the trees. This is possible as the animals feeds on the fruits of the trees and then comes in direct contact with humans which makes it possible for the virus to be transmitted from the infected animals to humans, hence zoonosis.

The growth of large intensively managed commercial pig farms in Malaysia with fruit trees on the farm created an environment where bats could drop partially eaten fruit contaminated with NiV laden bat saliva into pig stalls. The pigs could eat the fruit, become infected with $\mathrm{NiV}$, and efficiently transmit virus to other pigs because of the dense pig population on the farms, frequent respiratory shedding of the virus among infected pigs [49] and the pigs' high birth rate that regularly brought newly susceptible young pigs into the population at risk [50]

\section{ANIMAL MODELS OF NIPAH VIRUS DISEASE:}

\section{Nipah virus host species: flying foxes and pigs}

Experimental Nipah virus inoculations have been performed in some of its natural reservoir species, grey-headed fruit bats ( $P$. poliocephalus) and large flying foxes ( $P$. vampyrus), and in the intermediate host, domestic pigs.
Virus shedding upon inoculation of large flying foxes was minimal, with viral RNA detected in only two swabs from one out of eight infected bats (one throat and one rectal swab). Nipah virus RNA was detected in the urine of one of 17 inoculated grey-headed flying foxes, but not in any of the conjunctival, tonsillar, nasal or rectal swabs collected from these animals. Nipah virus isolation from bat tissues was rare and was only successful on day 7 after inoculation. Although some histopathological lesions were observed in inoculated bats, there was no detection of Nipah virus antigen associated with these lesions, so whether these lesions were caused by Nipah virus replication remains inconclusive. All inoculated bats sera converted, although virus neutralizing titres were generally low [51,52]. Experimental Nipah virus inoculations have also been performed in its intermediate, amplifying host, pigs. Oral inoculation of pigs did not result in clinical disease, but animals did develop a neutralizing antibody response.

Subcutaneous as well as a combination of intranasal, ocular and oral inoculation resulted in neurological and respiratory disease, albeit not in all inoculated animals [53,54]. The most common histopathological findings in pigs were meningitis and encephalitis; in pigs with severe clinical disease broncho interstitial pneumonia, systemic vasculitis and focal necrosis of spleen and lymph nodes were also observed. Viral antigen was detected in endothelial and smooth muscle cells of the brain, lungs and lymphoid system. Neurons, glial cells, epithelial cells of the upper as well as lower respiratory tract were also positive by immune histochemistry $[53,54]$.

Figure 2 below is showing the transmission of Nipah Virus from infected animals to humans. Nipah virus (NiV) is a zoonotic virus (it is transmitted from animals to humans) and can also be transmitted through contaminated food or directly between people. In infected people, it causes a range of illnesses from asymptomatic (subclinical) infection to acute respiratory illness and fatal encephalitis. "Its is a zoonotic disease (spreads from animals to humans) and its transmission can happen through infected bats by their bite or indirectly by consuming fruits like mangoes or date palm sap contaminated by their saliva, close contact with infected pigs or patients of Nipah virus infection. Human who 
have direct contact with infected fruit bats or infected pigs is the usual way an outbreak begins. However, consumption of raw date palm sap contaminated with bat faeces is another common way to get the disease. Human-tohuman transmission occurs during close contact between family members and/or medical caregivers.
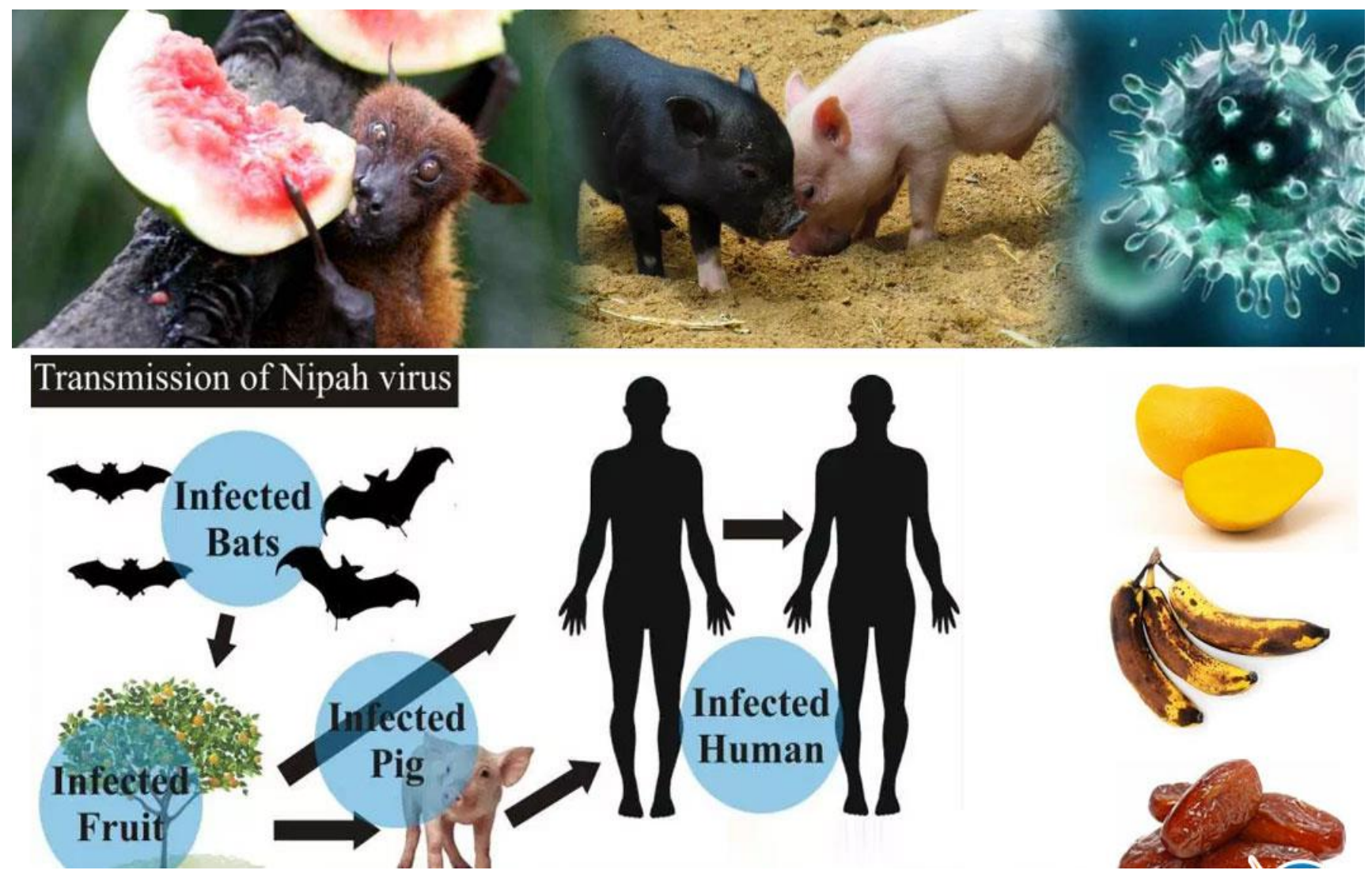

Figure 2: Transmission from infected Animals to Humans

\section{Syrian hamsters}

Upon inoculation with Nipah virus, Syrian hamsters developed respiratory and neurological disease; higher inoculum doses resulted in rapid development of lethal respiratory disease and lower doses resulted in the development of neurological signs. Several studies have shown that the route of inoculation has an effect on the development of disease, with disease progressing more rapidly and time to death being shorter upon intraperitoneal inoculation as compared to intranasal inoculation. Like human patients, the main histopathological finding in Syrian hamsters infected with Nipah virus was systemic vasculitis. Moreover, animals developed encephalitis and neurons in the CNS were clearly infected; viral antigen was detected by immunohistochemistry and inclusion bodies were observed that were shown to be nucleoprotein aggregates by electron microscopy. In hamsters that developed severe respiratory disease, usually upon intranasal inoculation with a high inoculum dose, rhinitis was observed, with virus replicating in the respiratory as well as olfactory epithelium, bronchointerstitial pneumonia developed in the lungs of these animals [54].

\section{Ferrets}

Ferrets inoculated oronasally with Nipah virus developed respiratory as well as neurological signs of disease. Systemic vasculitis was present in infected ferrets. Histologically, the upper respiratory tract, with rhinitis, tonsillitis and nasopharyngitis, as well as the lower respiratory tract, with necrotizing bronchointerstitial pneumonia, were affected; focal necrosis was detected in the spleen $[55,56]$. Encephalitis was not detected, but nonsuppurative meningitis occurred in a subset of animals and viral antigen was detected in brain endothelial cells and meninges, and occasionally in neurons and glial cells close to infected endothelium. 
Cats inoculated with Nipah virus subcutaneously or intranasally and orally developed signs of respiratory disease. Histologically, cats developed bronchointerstitial pneumonia and, in some animals, meningitis $[53,57]$.

\section{Methods}

\section{Case Definition and Clinical Sample Collection}

A team of physicians and epidemiologists from the National Institute of Virology, Pune, India, along with local public health authorities, visited Siliguri. Investigations were conducted with the assistance of health authorities from West Bengal State and staff from the North Bengal Medical College Hospital. Medical records of patients who were hospitalized during the study period were examined, and their family members or caretakers were interviewed. Areas of the town in which cases occurred and the houses of patients who died were visited. Contacts and family members of patients who died were also interviewed. A broad working case definition was used for case detection. The case definition evolved over the course of the outbreak on the basis of information from case-patients admitted to different hospitals, review of the line list of patients, and interviews with contacts in the community. A suspected patient was one $>15$ years of age with acute. onset of high-grade fever and headache. A probable patient was one $>15$ years of age who had high-grade fever and altered sensorial and encephalitis of unknown origin. Blood samples were available for 18 hospitalized patients and for 13 family contacts of patients who died 2-3 weeks earlier. Six urine samples (5 samples had corresponding serum samples) were also collected [11]

\section{Serologic Testing}

State health authorities conducted laboratory tests to rule out malaria and bacterial infections. Serologic tests to detect infection by Japanese encephalitis virus, West Nile virus, measles virus, dengue virus, Leptospira spp., and hantavirus were carried out at the National Institute of Virology. Serum samples were gamma-irradiated at the Centers or Disease Control and Prevention (CDC) before being tested for immunoglobulin $\mathrm{G}$ ( $\mathrm{IgG}$ ) and $\mathrm{IgM}$ antibodies to $\mathrm{NiV}$ and measles by enzyme-linked immunosorbent assay (ELISA), as previously described. Briefly, inactivated antigens for these ELISAs were prepared from gamma (60Co)irradiated NiV-infected or mock-infected Vero E6 cells. Serum samples were tested in 4-fold dilutions from 1:100 to 1:6,400. Samples were considered positive for the IgM assay if the sum of the adjusted optical densities (OD) from all of the dilutions (OD from infected antigen well minus OD from the mock-infected antigen) was $>0.75$ through the entire dilution series, and the titer was >1:400. Similarly, samples were considered positive for IgG if the sum for the adjusted OD from all the dilutions was $>0.90$ through the entire dilution series, and the titer was $>1: 400$ [11].

\section{Case Identification and Sample Collection}

We conducted this study in 3 Nipah surveillance hospitals at Faridpur, Rajshahi, and Rangpur, Bangladesh, during December 2013-April 2014. Surveillance physicians identified patients admitted with encephalitis, defined as fever or history of fever with axillary temperature $>38.5^{\circ} \mathrm{C}\left(101.3^{\circ} \mathrm{F}\right)$ and altered mental status, new onset of seizures, or new neurologic deficit and collected blood and oral swab samples. Because of resource constraints, surface sampling for all encephalitis cases was not possible; therefore, a research assistant swabbed hospital surfaces near encephalitis patients with a history of consuming raw date palm sap, contact with another encephalitis patient, or both. Occasionally, physicians from other nearby hospitals reported suspected Nipah case-patients to public health authorities. These patients also had biological samples collected for laboratory testing but were not included in the surface sampling study [11].

Blood samples were centrifuged at the local government health facility, and the separated serum was stored and transported to the Institute of Epidemiology Disease Control and Research laboratory in a liquid nitrogen dry shipper ($150^{\circ} \mathrm{C}$ ) and then stored at $-20^{\circ} \mathrm{C}$ until testing. From each patient, 1 oral swab was collected in $1 \mathrm{~mL}$ of nucleic acid extraction lysis buffer every consecutive day for 7 days, until hospital discharge or death, whichever occurred first [11]. 
A research assistant collected 1 swab sample from up to 5 areas near each patient: the wall beside patient bed, bed rail, bed sheet, clinical record file, and multipurpose towel used by family caregivers for cleaning patient secretions, drying hands, and other caregiving purposes. The research assistant collected surface swab samples at least 12 hours after the patient was admitted to the hospital. With 1 sterile rayon swab stick per surface, the research assistant swabbed the area of the wall in contact with the bed $45 \mathrm{~cm}$ high from the level of the bed sheet; all surfaces of the bed rail in the area near the patient's head; half of the bed sheet where the patient's head was, including underneath the patient; front and back covers of the patient file; and both sides of the multipurpose towel. Not all patients had a wall or bed rail near them because some patients were cared for on the floor and some were away from the walls. One swab sample per surface area was collected in separate cryovials with $1 \mathrm{~mL}$ of nucleic acid extraction lysis buffer (bioMérieux, Marcy-l'Étoile, France). The vials were kept in a cool box maintaining a temperature of $2^{\circ}-8^{\circ} \mathrm{C}$ for up to 30 min after collection and then were placed in a liquid nitrogen dry shipper for storage and transportation [11].

\section{Community Investigation}

An investigation team visited the communities of encephalitis patients identified at surveillance hospitals who had NiVIgM in serum to identify any other associated encephalitis cases. The team interviewed identified encephalitis patients and their caregivers using a structured questionnaire. Identified patients were asked about the nature of their contact with hospitalized patients (i.e., touching, being in the same room, feeding, sharing a bed, or cleaning body secretions) to find evidence of person-toperson transmission. The team also collected blood from the encephalitis patients identified in the community investigation [11].

\section{CONCLUSION}

An infectious disease outbreak in south India that has left at least 16 people dead has brought the world's attention to a little-known health threat: the Nipah virus. An emerging zoonotic virus whose natural host is the Pteropus fruit bat, Nipah virus was first recognised in the late 1990s when an outbreak in pigs in Malaysia and Singapore moved to humans, killing 106 people. Since then, interest in Nipah virus has remained limited to small research communities and affected countries. Annual outbreaks occur in Bangladesh, where humans are exposed through consumption of the sap of date palm trees contaminated by infected bats. Worryingly, Nipah virus can also be transmitted from human to human, as in the current south India outbreak, with most cases occurring in family members or health workers caring for individuals sick with the high fever, vomiting, and breathing difficulties characteristic of infection. Severe cases can lead to respiratory syndrome, encephalitis, and death - the case fatality rate may be up to $75 \%$. There is no cure, vaccine, or specific treatment-supportive care is the most that can be offered to affected individuals. Nipah virus infection has so far been limited to countries in south and east Asia, where 600 cases have been reported between 1998 and 2015, according to WHO. And all the cases was caused by the transmission from the bats to plants fruits and from that it was transferred to the pigs then it come in contact with the humans and then the human suffers from it. Mostly in humans it is transferred by the infected fruits which is been consumed by the humans due to the lack of awareness about the infected fruits which is increasing the number of cases day by day.

\section{ACKNOWLEDGEMENT}

The authors are thankful to IJIST Journal for publishing their article.

\section{CONFLICTS OF INTEREST}

The author declares that there are no conflicts of interest.

\section{REFERENCES}

1. Kumar S. Inadequate research facilities fail to tackle mystery disease. BMJ. 2003; 326:12.

2. Chua KB, Bellini WJ, Rota PA, Harcourt BH, Tamin A, Lam SK, et al. Nipah virus: a recently emergent deadly paramyxovirus. Science. 2000; 288:1432-5.

3. ICDDRB. Nipah encephalitis outbreak over wide area of western Bangladesh. Health Science Bulletin. 2004; 2:7-11.

4. ICDDRB. Person-to-person transmission of Nipah virus during outbreak in Faridpur District. Health Science Bulletin. 2004; 2:5-9. 
5. World Health Organization. Nipah virus outbreak(s) in Bangladesh, January-April 2004. WklyEpidemiol Rec. 2004; 17:168-71.

6. Hsu VP, Hossain MJ, Parashar UD, Ali MM, Ksiazek TG, Kuzmin I, et al. Nipah virus encephalitis reemergence, Bangladesh. Emerg Infect Dis. 2004; 10:2082-7

7. Yob JM, Field H, Rashdi AM, Morrissy C, van der Heide B, Rota P, et al. Nipah virus infection in bats (order Chiroptera) in peninsular Malaysia. Emerg Infect Dis. 2001; 7:439-41.

8. Olson JG, Rupprecht C, Rollin PE, An US, Niezgoda M, Clemins T, et al. Antibodies to Nipah-like virus in bats (Pteropuslylei), in Cambodia. Emerg Infect Dis. 2002; 8:987-8.

9. Chua KB, Koh CL, Hooi PS, Wee KF, Khong JH, Chua $\mathrm{BH}$, et al. Isolation of Nipah virus from Malaysian Island flying-foxes. Microbes Infect. 2002; 4:145-51.

10. Reynes JM, Counor D, Ong S, Faure C, Seng V, Molia S, et al. Nipah Virus in Lyle's flying foxes, Cambodia. Emerg Infect Dis. 2005:11; 1042-7.

11. Mandeep S. Chadha, James A. Comer et al. Nipah Virus associated Encephalitis outbreak, Siliguri, India.

12. Institute of Epidemiology, Disease Control and Research (IEDCR). Nipah Infection in 2013-Update on $5 \mathrm{Feb}, 2013$

13. World Health Organization Global Early Warning System for Major Animal Diseases, including Zoonoses. Zoonoses \& Vet Pub Hlth. 2007 (http://www.who.int/zoonoses/outbreaks/glews/en/ind ex.html).

14. Chadha MS, Comer JA, Lowe L, Rota PA, Rollin PE, Bellini WJ, Ksiazek TG, Mishra A. Nipah virusassociated encephalitis outbreak, Siliguri, India. Emerg Infect Dis. 2006; 12(2):235-40.

15. Harit AK, Ichhpujani RL, Gupta S, Gill KS, Lal S, Ganguly NK, Agarwal SP. Nipah/Hendra virus outbreak in Siliguri, West Bengal, India in 2001. Indian J Med Res. 2006; 123:553-60.

16. Chua KB, Koh CL, Hooi PS, Wee KF, Khong JH, Chua BH, Chan YP, Lim ME, Lam SK. Isolation of Nipah virus from Malaysian Island flying-foxes. Microbes Infect. 2002; 4:145-51.

17. International Centre for Diarrheal Disease Research, Bangladesh (ICDDRB). Person-to-person transmission of Nipah virus during outbreak in Faridpur District. Health Sci Bull. 2004; 2:5-9.

18. World Health Organization. Nipah virus outbreak(s) in Bangladesh, January-April 2004.WklyEpidemiol Rec. 2004; 17:168

19. Nowak RM. Walker's bats of the world. Baltimore: The Johns Hopkins University Press; 1994.

20. Harcourt BH, Lowe L, Tamin A, Liu X, Bankamp B, Bowden N, Rollin PE, Comer JA, Ksiazek TG, Hossain MJ, Gurley ES, Breiman RS, Bellini WJ, Rota PA. Genetic characterization of Nipah viruses isolated during two outbreaks in Bangladesh in 2004. Emerg Infect Dis. 2005; 11:1594-7.

21. Reynes JM, Counor D, Ong S, Faure C, Seng V, Molia S, Walston J, Georges-Courbot MC, Deubel V, Sarthou JL. Nipah virus in Lyle's flying foxes, Cambodia. Emerg Infect Dis. 2005; 11:1042-7.
22. Krishnan S. Nipah outbreak in India and Bangladesh, WHO Communicable Disease Department Newsletter. 2007; 4(2).

23. Arankalle VA, Bandyopadhyay BT, Ramdasi AY, Jadi R, Patil DR, Rahman M, Majumdar M, Banerjee PS, Hati AK, Goswami RP, Neogi DK, Mishra AC. Genomic characterization of Nipah virus, West Bengal, India. Emerg Infect Dis. 2011; 17:907-9.

24. Chua KB, Bellini WJ, Rota PA, et al. Nipah virus: a recently emergent deadly paramyxovirus. Science May 26; 2000 288(5470):1432-5. [PubMed: 10827955]

25. Paton NI, Leo YS, Zaki SR, et al. Outbreak of Nipahvirus infection among abattoir workers in Singapore. Lancet Oct 9; 1999 354(9186):1253-6. [PubMed: 10520634]

26. Chua KB. Nipah virus outbreak in Malaysia. J ClinVirol Apr; 2003 26(3):265-75. [PubMed: 12637075]

27. Parashar UD, Sunn LM, Ong F, et al. Case-control study of risk factors for human infection with a new zoonotic paramyxovirus, Nipah virus, during a 19981999 outbreak of severe encephalitis in Malaysia. The Journal of Infectious Diseases May; 2000 181(5):1755-9. [PubMed: 10823779]

28. Goh KJ, Tan CT, Chew NK, et al. Clinical features of Nipah virus encephalitis among pig farmers in Malaysia. The New England Journal of Medicine Apr 27; 2000 342(17):1229-35. [PubMed: 10781618]

29. Uppal PK. Emergence of Nipah virus in Malaysia. Annals of the New York Academy of Sciences 2000; 916:354-7. [PubMed: 11193645]

30. Yob JM, Field H, Rashdi AM, et al. Nipah virus infection in bats (order Chiroptera) in peninsular Malaysia. Emerging Infectious Diseases May-Jun; 2001 7(3):439-41. [PubMed: 11384522]

31. Daszak, P, Plowright, R, Epstein, JH, Pulliam, J, Abdul Rahman S. Field, HE.; Smith, CS.; Olival, KJ.; Luby, S.; Halpin, K.; Hyatt, AD.; HERG. The emergence of Nipah and Hendra virus: pathogen dynamics across a wildlife-livestock-human continuum. In: Collinge, SRS., editor. Disease Ecology: Community structure and pathogen dynamics. Oxford University Press; Oxford: 2006. p. 186-201.

32. Reynes JM, Counor D, Ong S, et al. Nipah virus in Lyle's flying foxes, Cambodia. Emerging Infectious Diseases Jul; 2005 11(7):1042-7. [PubMed: 16022778]

33. Wacharapluesadee S, Lumlertdacha B, Boongird K, et al. Bat Nipah virus, Thailand. Emerging Infectious Diseases Dec; 2005 11(12):1949-51. [PubMed: 16485487]

34. Epstein JH, Prakash VB, Smith CS, et al. Henipavirus infection in Fruit Bats (Pteropusgiganteus), India. Emerging Infectious Diseases 2008;14(8)

35. Hsu VP, Hossain MJ, Parashar UD, et al. Nipah virus encephalitis reemergence, Bangladesh. Emerging Infectious Diseases Dec; 2004 10(12):2082-7. [PubMed: 15663842]

36. Iehle C, Razafitrimo $\mathrm{G}$, Razainirina $\mathrm{J}$, et al. Henipavirus and Tioman virus antibodies in pteropodid bats, Madagascar. Emerging Infectious 
Diseases Jan; 2007 13(1):159-61. [PubMed: 17370536]

37. Chua KB, Koh CL, Hooi PS, et al. Isolation of Nipah virus from Malaysian Island flying-foxes. Microbes and infection / Institut Pasteur Feb; 2002 4(2):145-51. [PubMed: 11880045]

38. Middleton DJ, Morrissy CJ, van der Heide BM, et al. Experimental Nipah Virus Infection in Pteropid Bats (Pteropuspoliocephalus). Journal of Comparative Pathology May; 2007 136(4):266-72. [PubMed: 17498518]

39. Nowak, R. Walker's Bats of the World. Johns Hopkins University Press; Baltimore: 1994.

40. Bates, PJJ.; Harrison, DL. Bats of the Indian Subcontinent. Harrison Zoological Museum; Kent, UK: 1997.

41. Middleton DJ, Westbury HA, Morrissy CJ, et al. Experimental Nipah virus infection in pigs and cats. Journal of Comparative Pathology. 2002 FebApr;126(23):124-36. [PubMed]

42. Epstein JH, Field HE, Luby S, Pulliam JR, Daszak P. Nipah virus: impact, origins, and cause of emergence Current Infectious Disease reports. 2006 Jan;8(1):59_ 65. [PubMed]

43. Paton NI, Leo YS, Zaki SR, et al. Outbreak of Nipahvirus infection among abattoir workers in Singapore.Lancet.1999; 354:1253-1256. [PubMed: 10520634]

44. Chong HT, Kunjapan SR, Thayaparan T, et al. Nipah encephalitis outbreak in Malaysia, clinical features in patients from Seremban. The Canadian journal of neurological sciences Le journal canadien des sciences neurologiques.2002; 29:83-87. [PubMed: 11858542]

45. Hossain MJ, Gurley ES, Montgomery JM, et al. Clinical presentation of nipah virus infection in Bangladesh. Clin Infect Dis. 2008; 46:977-984. [PubMed: 18444812]

46. Chong HT, Hossain J, Tan CT. Differences in epidemiologic and clinical features of Nipah virus encephalitis between the Malaysian and Bangladesh outbreaks. Neurology Asia.2008; 13:23-26.

47. Sejvar JJ, Hossain J, Saha SK, et al. Long-term neurological and functional outcome in Nipah virus infection. Ann Neurol. 2007; 62:235-242. [PubMed: 17696217]

48. Tan CT, Goh KJ, Wong KT, et al. Relapsed and lateonset Nipah encephalitis. Ann Neurol. 2002; 51:703708. [PubMed: 12112075]

49. Wong SC, Ooi MH, Wong MN, et al. Late presentation of Nipah virus encephalitis and kinetics of the humoral immune response. Journal of neurology, neurosurgery, and psychiatry.2001; 71:552-554.

50. Wong KT, Shieh WJ, Kumar S, et al. Nipah virus infection: pathology and pathogenesis of an emerging paramyxoviral zoonosis. Am J Pathol.2002; 161:2153-2167. [PubMed: 12466131]

51. Halpin K, Hyatt AD, Fogarty R, et al. Pteropid bats are confirmed as the reservoir hosts of henipaviruses: a comprehensive experimental study of virus transmission. The American journal of tropical medicine and hygiene.2011; 85:946-951. [PubMed: 22049055]

52. Middleton DJ, Morrissy CJ, van der Heide BM, et al. Experimental Nipah virus infection in pteropid bats (Pteropuspoliocephalus). J Comp Pathol.2007; 136:266-272. [PubMed: 17498518]

53. Middleton DJ, Westbury HA, Morrissy CJ, et al. Experimental Nipah virus infection in pigs and cats.J Comp Pathol.2002; 126:124-136. [PubMed: 11945001]

54. Weingartl H, Czub S, Copps J, et al. Invasion of the central nervous system in a porcine host by nipah virus. J Virol.2005; 79: 7528-7534. [PubMed: 15919907]

55. Bossart KN, Zhu Z, Middleton D, et al. A neutralizing human monoclonal antibody protects against lethal disease in a new ferret model of acute nipah virus infection. PLoSPathog. 2009; 5:e1000642. [PubMed: 19888339]

56. Clayton BA, Middleton D, Bergfeld J, et al. Transmission routes for nipah virus from Malaysia and Bangladesh. Emerg Infect Dis. 2012; 18:19831993. [PubMed: 23171621]

57. Mungall BA, Middleton D, Crameri G, et al. Feline model of acute nipah virus infection and protection with a soluble glycoprotein-based subunit vaccine. J Virol.2006; 80:12293-12302. [PubMed: 17005664] 